\title{
Teachers' Perceptions on the Relationship Between Teachers' Working Conditions and Pupils' Reading Ability in Pre-Primary Schools in Nakuru County, Kenya
}

\author{
*Mary M. Kimwomi Gladwell Wambiri Maureen Mweru \\ School of Education, Kenya University, P.O. Box 43844 - 00100, Nairobi, Kenya
}

\begin{abstract}
One of the most important factors in realizing reading as a subject in pre-primary schools is teacher working conditions. Literature suggests that working conditions are crucial in teaching of reading and pupils' reading ability. However, empirical studies that have examined pupils' reading ability have not focused on the relationship between teacher working conditions and reading ability. Further, the few empirical studies that have examined the relationships have been conducted in primary and secondary schools. Whereas most pre-primary school teachers in Kenya work under unfavourable conditions, past studies have not examined the relationship between working conditions and reading ability of pre-primary school pupils in Kenya. The purpose of this study was to examine the relationship between teacher working conditions and pupils' reading ability. The study was based on Herzberg's two factor theory. The study adopted a correlational research design. The target population for the study was 79 head teachers and 79 pre-primary 2 class teachers in public schools in Rongai Sub-County Nakuru. A stratified sample of pre-primary schools in the four zones in Rongai Sub-county was used for the study. The sample size comprised of 66 head teachers and 66 pre-primary 2 teachers. The questionnaires were used to collect data from respondents.. Data was summarized using descriptive statistics such as frequencies, means and standard deviations. To test the hypotheses, Pearson's Product-moment correlation coefficient was used. The results revealed that there was a relationship between teacher workload, school leadership and pupils' reading ability. The study concludes that teacher workload and school leadership affect the reading ability of preprimary school pupils. The study recommends that to improve reading ability, school management should provide effective school leadership and ensure that pre-primary school classes are of reasonable sizes so that teachers do not have a heavy workload.
\end{abstract}

Keywords: Working Conditions, Teacher Workload, School Leadership, Reading Ability; Pre-primary School Pupils

DOI: $10.7176 / \mathrm{JEP} / 10-18-23$

Publication date:June $30^{\text {th }} 2019$

\section{Introduction}

Reading ability from early childhood years serves as an essential foundation in a child's future academic achievement. It is an active process of understanding print and graphic text (Grabe, 1991; Van, 2002). Reading experience affects a learner's self image and feeling of competence. Reading is an important means of acquiring knowledge, skills and self expression in the modern world of expansion of technology. It is vital in providing the information needed to fully understand how things happen (Aina, Taiwo, Okusaga, \& Ogundipe, 2011). Aina et al. (2011) further describe reading as a form of entertainment and an important life skill, which has to be nurtured from the early years of pupils' development. Further, reading failure is associated to misbehaviour, anxiety and lack of motivation (Van, 2002). According to Grabe (1991) reading develops through cognitive and social processes that exist in wide social and cultural environments. Grabe further observes that reading involves the ability to decode written words, comprehend what is written in texts and interpretation skills. This means that readers are not passive during the reading process but instead, understand and construct meaning in the reading process.

Reading is paramount to learning in schools, workplaces and in everyday life; and how well a child is able to read is associated to the child's academic success (Elley, 1991). Elley further noted that academic achievement was as a result of early comprehension skills, and therefore pupils' reading ability should develop at an early age to avoid problems associated with reading and comprehending texts in other subjects learnt in school. Lipson and Wixson (1997) argue that reading does not only involve decoding the written word, but also includes mental skills that enable the reader to monitor, understand and assess his own reading methods as he is involved in reading for different purposes. Pupils who spend more time reading are better readers and are active participants in all reading activities rather than passive listeners (Guthrie et al., 2004). Guthrie further links reading ability with the amount of reading an individual engages in; the more a person reads, the better he can perform in other subjects.

An understanding of the working conditions that promote teachers' efforts in teaching is crucial in supporting pupil's reading ability. Ingersoll (2001) noted that, lack of professional competence in teachers, 
intrusion on teaching time, large class sizes, inadequate time to prepare, lack of faculty influence, lack of student discipline, and unsafe environment were the leading causes of teacher dissatisfaction and poor performance. Ye (2016) noted that teachers' working conditions were important in delivering quality education and teachers who were devoted in their work would always prefer working in environments that could support their teaching.

Once pupils have developed reading skills, they need to be supported in order to reach their full potential. Pupils whose reading skills are not fully developed receive poor grades in other school subjects, have behavioural problems, do not like school and finally do not develop to their full potential. Good reading habits assist pupils in developing a steady and constructive mind. Large and growing numbers of children in Nigeria, reach upper elementary classes not able to read and understand class level appropriate materials. Most of them are unable to read because they are lazy and accommodate many distractions around them such as television, radio, social activities and inability to do any serious reading (Aina et al., 2011).

According to the Kenyan Pre-primary school Syllabus (Republic of Kenya, 2008), the competences in oral activities, vocabulary and comprehension describe reading ability. It is therefore important for teachers to introduce their pupils to early reading strategies since reading is the key to academic achievement and other daily activities (Wambiri, 2014). Moreover, pupils who are good in the above aspects are regarded to be developed in reading ability

A study carried out to investigate the reading achievement in Kenya by National Assessment for Monitoring Learner Achievement (NASMLA, 2012) revealed that slightly less than half (47.7\%) of the pupils attained the desirable levels of class three and four competency in literacy. Further, only about a half (46.1\%) of class three pupils demonstrated emergent reading ability which was congruent with class two levels. In addition a study by Uwezo (2011) conducted in Kenya, reported that nationally, only seven out of 100 pupils in class six to eight could comprehend a class two level story even when they could read. Furthermore eight of them were unable to read a simple English story. A more current study by Uwezo (2015) revealed that learning outcomes were low nationally. The study further revealed that three out of 10 standard three pupils could read standard two English story book, while two out of 10 in the same class could not read an English word. Karuoya (2015) also showed that in Kenya, a significant percentage of pupils $(15.3 \%)$ had reading problems and $17.6 \%$ of the pupils could not understand what they read. Mwoma (2017) showed that school outcomes and perfect academic performance in all subjects taught, depended on the ability of pupils to read. Therefore pupils, who are exposed to pre-reading activities at an early age, learn how to read than those who are introduced to it at an older age, and struggle to learn the more advanced reading skills acquired through reading.

In Kenya, it is mandatory for all pupils to go through pre-primary school education before joining primary schools. This requirement has led to an increase in enrolment of pupils in both public and private pre-primary schools leading to heavy teacher workload (Republic of Kenya, 2006). Working conditions of teachers is therefore strained, thus affecting teaching of reading and pupils' ability to read. Some of the challenges associated with high enrolment include overstretched facilities, poor health and sanitation and poor quality assurance (Republic of Kenya, 2006). In some counties such as Turkana, pupils teach themselves as there is a shortage of teachers, classrooms and learning materials (Ng'asike, 2011).

Theoretical Literature suggests that working conditions such as teacher workload and school leadership are crucial in teaching of reading and pupils' reading ability. However, empirical studies that have examined pupils' reading ability have not focused on the relationship between teacher working conditions and reading ability. The few empirical studies that have examined the relationships have been conducted in primary and secondary schools. Whereas most pre-primary school teachers in Kenya work under unfavourable conditions, prior studies have not examined the relationship between teachers' working conditions and pupils' reading ability.

The purpose of this study was to examine the relationship between teacher working conditions and pupils' reading ability. Specifically, this study sought to investigate the relationship between teacher workload and school leadership, and pupils' reading ability in pre-primary class pupils in public pre-primary schools.

The study sought to test the following hypotheses:

$\mathrm{Ho}_{1}$ There is no relationship between teacher workload and pupils' reading ability.

$\mathrm{Ho}_{2}$ There is no relationship between school leadership and pupils' reading ability.

\section{Literature Review}

\subsection{Teacher Workload and Pupils' Reading Ability}

Teachers' workload has been a subject in many studies. Teacher workload has been associated with emotional exhaustion (Janssen, Schaufeli, \& Houkes, 1999). Bennett, Weigel, and Martin (2002) argued that teaching time, inadequate time to prepare, and large classroom sizes were some of the factors that affected the commitment of teachers in teaching reading. Ingersoll (2001) was of the opinion that less hours for lesson preparation and large class sizes were some of the reasons that made teachers de-motivated in teaching.

A survey study by Berry, Smylie and Fuller (2008) on teacher working conditions in Chicago schools found that teachers were working longer hours than previous years. Teachers spent 50 hours per week on teaching and 
12 hours per week on unpaid school related activities like grading papers, bus duty, student club activities and advising students. In their comparison of schools serving whites and colour students, Berry et al. found that whites had smaller classes which tended to motivate the teachers to teach students well, and especially provide more one-on-one interaction that aimed at meeting individual student needs. Berry et al. also found that overcrowding of students in one class led to increased aggression and less student involvement in all activity areas in the school, thereby, small classes were found to be effective in closing the achievement gap. Berry et al.'s (2008) study further revealed that smaller class size such as 25 students per class performed well in reading than schools with large numbers of pupils. Smaller number meant that the classes were not big and therefore the teacher workload was not heavy, which gave them ample time to do their class work better. Reduction in teacher workload increased teacher satisfaction and that small class size provided room for individual interaction with pupils. The study dealt with working conditions in Chicago schools, but did not specifically show how these working conditions could affect teachers' ability to teach reading and the reading ability of pupils, hence the need for the current study.

Bennett (2002) identified some of the conclusions drawn by teachers regarding class size. Some teachers felt that smaller number of children in class resulted in increased teacher student direct contact, while others felt there was no significant for pupils with lower academic ability. According to Bennett (2002) teacher workload impacted negatively to teachers morale, which in turn affected the way they responded to pupils and thus leading to inability to teach children properly hence poor a academic performance. A study by Lemerle (2005) which examined the impact of the school environment on teachers' health and job commitment in Australian schools revealed that time, workload pressures, tension with staff, administrative and community factors were thought to be stressors among many teachers, leading to many teachers deciding to leave teaching profession.

Dehaloo (2011) in a study on the motivation and job satisfaction of secondary school teachers in KazuluNatal revealed that, very few teachers never complained about their aspect of workload. Majority of the teachers were reported to have pastoral duties other than teaching because they felt that their working conditions were not favourable. Dehaloo (2011) further found that teachers of between 27 to 39 years with work experience of between 6 to 15 years were least motivated in their work places, as compared to their counterparts of between 40 to 54 years with 6 to 25 years of experience. Dehaloo (2011) also revealed that male teachers were more satisfied than female teachers with school policy, interpersonal relations and schools' overall organization. Maicibi (2003) noted that increasing hours of work, large class sizes, teaching more subjects and constantly changing the curricular were major factors that affected teachers' commitment to teach in schools. Mayeku (2009) was of the opinion that understaffing led to heavy workload for the teachers and impacted greatly on the quality of the services offered thus affecting the quality of the programmes. On the other hand, Wawitwa (2009) established that in order to reduce the teacher workload, more teachers had to be deployed so that they could have enough time for preparing practical lessons. Waseka, Simatwa and Okwach (2016) found that high teaching loads affected a teacher's ability to assist students to perform well in the Kenya Certificate of Secondary Education. They further revealed that schools which were understaffed and teachers overloaded with work, attained poor results in National examinations. On the contrary, those schools that had enough teachers had students who performed well in the Kenya Certificate of Secondary Education.

A study conducted by Crouch, Korda and Mumo (2009) in Malindi, Kenya to examine improvement of reading skills revealed that there were large enrolment of pupils' in schools against few teachers on the ratio of 1:65. The study reported that such large class sizes made teachers to have difficult times in teaching reading and especially marking pupils' work hence, teachers gave children few assignments. According to UNESCO (2005), schools with large class sizes have difficulties in reaching individual children, thus affecting academic performance.

\subsection{School Leadership and Pupils Reading Ability}

Literature suggests that school leadership has an impact upon teachers' ability to teach reading. School leadership involves guidance, support and behaviours necessary to change the whole performance process and clear personal and professional values. Sergiovanni (2009) argues that for teachers to perform well in teaching reading there should be good school administrators. Sergiovanni further asserts that schools should create environments that facilitate teachers to accomplish their tasks. According to Sergiovanni, teachers have to participate in decision making in matters related to their class work, have reasonable autonomy to execute their duties, share purpose, and receive recognition, treated with respect and dignity by being given ample staff development opportunities so as to develop further. Danielson (2010) associated school leadership to a key factor in the management and shaping the cultural information for supporting students' academic progress. Danielson was of the opinion that in order for good leadership to take place; change must be collective efforts of school principals, teachers, schools and communities, hence good academic performance. Farr (2011) agrees with Danielson's opinion that school leaders who are serious with their work assist teachers to be good role models and embody values and success in teaching. Farr further noted that excellent teaching emerged from 
good school leadership which consisted of applying and being capable of transferring knowledge. A survey study by Markel (2004) looking at the condition of teachers in North America, demonstrated that administrative support played a big role in teachers' decision making, of whether to stay or leave the teaching profession.

Lemerle (2005) found that conducive school environment was as a result of higher levels of teacher participation in decision-making processes, administrators' clear articulate of work expectations, genuine concern for the welfare of the teachers, friendliness, openness and trust among staff. In their study, Berry et al. (2008) found that there was a relationship between teacher decision making and remaining in the teaching profession. They noted that teachers who were given freedom of expression by their school principals were happy and therefore, carried their classroom activities very well. Further, Berry et al. found that open communication between principals and teachers made teachers satisfied and happy while working with children, unlike the principals who appeared to be harsh and who practised an authoritarian kind of leadership when doing administrative duties. These previous studies focused on decision making and communication by the school principals as determinants of school leadership factors, therefore creating the gap for the current study.

Teachers' professional development is very important in promoting the reading ability of pupils. A study by Berry et al. (2008) revealed that schools that performed well in academic studies were as a result of taking part in professional development. Berry's study further revealed that school administrators who were chilly, distant and manipulative had teachers who were not satisfied and committed in their work. On the other hand school administrators who were warm, caring and honest often had teachers who were jolly and committed to their work. Teachers who were free to work with and consult other teachers in both classroom work and researching on their children's learning abilities, made changes in teaching methods and especially teaching of reading (Johnson, 2006). According to UNESCO's (2008), school administrators should appreciate the usefulness of in-service education designed to improve the quality and content of education and teaching methods, that should be free of charge to all teachers. UNESCO further recommended that teachers be provided with opportunities to participate in courses and take full advantage of acquiring all required professional tasks.

Leithwood (2006) carried out a survey study on teacher working conditions that matter and evidence for change in secondary schools. The study found that job satisfaction had a strong and direct effect on teacher retention and that school principals determined the morale among beginning teachers by demonstrating good school leadership. Teachers expected principals who could communicate clearly by giving them instructional guidance and resources, rewarding them for good work done and helping in the enforcement of student rules of conduct. Leithwood suggested that the school principals should set direction for the school by being considerate, consultative, and supportive in staff development, managing the instructional program and in day-to-day interactions. The study was based on teacher working conditions that matter and evidence for change in secondary schools, hence, the need for the current study.

An empirical study by Lukhele (2007) on relationship between reading attitudes, reading ability and academic performance among teacher trainees in Swaziland, revealed that there was a positive relationship between teachers' motivation and reading among teacher trainees. According to Adedeji and Olaniyan (2011), teachers' de-motivation to teach across rural African countries was due to lack of administrative support, teacher input in decision making and the school climate. Adeyinka, Asabi and Adedotum (2013) also suggested that it was important for school managers to create working environment where everyone was highly valued, and that school managers should maintain good management skills and make teaching environment conducive for teachers. The study was based on reading attitudes and ability of teacher trainees thus, the need of the current study.

Gwambombo (2013) carried out a study on the effect of teacher workload on students' academic performance on community secondary schools found that the hours spent by one teacher in teaching, internal tests done, marking load, administrative and non administrative roles done by teachers' workload and also the students' school performance in local secondary schools. The study further showed that teachers who were exhausted, embarrassed and had heavy workload performed poorly in teaching and learning processes. Gwambombo concludes that teachers with heavy workload are not effective and efficient hence, leading to negative effects such as poor student academic performance. The study majorly focused on the effect of teacher workload on students' academic performance, therefore creating the gap for the current study.

A study by Kahenu (2005) on the factors that influence motivation and productivity of secondary school teachers in Thika, Kenya revealed that head teachers' good leadership style, promotion policy and physical facilities resulted in high academic performance in schools and especially reading. A study by Lusiola (2011) in Kegonga Division, Kuria East District, on the working conditions and their relationship to the level of motivation of pre-primary school teachers, revealed that there was no relationship between professional growth opportunities and motivation of pre-primary teachers. Findings of the study by Lusiola contradicted the finding of a study by Karugu (1980) who found that motivating job factors for Kenya elites included recognition, advancement (professional growth), work itself, responsibility and achievement. The study focused on working conditions and their relationship to the level of motivation but, did not focus on the relationship between teacher 
working conditions and pupils' reading ability thus, the need of the current study.

King'oo (2016) did a study on the factors influencing job satisfaction among teachers in public secondary schools in Machakos town sub-county, Kenya and found that school leadership depended on the number of teachers and their interpersonal skills in order to mentor and lays strong foundations, which could later lead to improved academic performance. King'oo further noted that leadership relies not only on an individual, but on the entire school community. Therefore, there was need for the current study to find out the effect of school leadership on reading ability of pre-primary pupils.

In a study examining the influence of selected motivational factors on the performance of secondary school agriculture teachers in Imenti South District, Kenya, Kirimi, Gikunda, Obara and Kibett (2013) found that there was a positive relationship between working conditions and performance of teachers. The study also showed that the teachers worked together in the school without any interference and had no problems in talking with their colleagues, principals and the deputy principals. Further, the research revealed that principals were responsible to the needs of the teachers and therefore team work prevailed. The above reviewed studies examined working conditions and leadership and teacher motivation. There was need therefore to examine the working conditions of teachers and pupils' reading ability in pre-primary level, thus the need for the current study.

\section{Methodology}

This study was conducted in Rongai Sub-County, Nakuru County, Kenya. Rongai Sub-County was considered suitable for the study because it covered both rural and urban settings and hence the pre-primary schools' environments differed with different effects on teacher working conditions. Having been a teacher in this SubCounty for five years, the researcher found that many pre-primary school pupils attained below average scores in reading tests administered to them as a requirement for transition from pre-primary school to primary school. This had alarmed the researcher and thus necessitated the study on the relationship between teachers working conditions and pupils' reading ability in pre-primary schools.

The study was a correlation study that sought to establish the nature and strength of the relationship between variables. The design was relevant in this study because it sought to examine the relationship between teachers' working conditions and pupils' reading ability. The researcher employed stratified sampling technique to select the pre-primary schools that were included in the sample. Each zone in Rongai Sub-County namely; Ngata, Solai, Kambi ya Moto and Rongai formed a stratum and then proportionate stratified sampling technique was used to ensure each was represented in the sample. The sampling frame was prepared using information provided by Rongai Sub-County Education Office. To select the schools from each zone to be included in the study, simple random sampling technique was used. Sample of public pre-primary schools was used in this study. The target population was 66 head teacher and 66 pre-primary school teachers were targeted in this study.

Primary data was collected using closed-ended questions. The questionnaires were developed on the dimensions of the research variables. In gathering the data, Likert-type questionnaires were used as research instruments. The questionnaires were self-administered to the respondents. Appendix II contains questions to establish pre-primary school profile; Appendix III is divided into three sections: Section A contains questions to establish profiles of pre-primary school teachers; Section B contains the questionnaire with items on a five point Likert-type scale from $1=$ 'never' to $5=$ 'very often' to measure the teachers' working conditions. Section C contains rating scale with items on a five point Likert-type from $1=$ 'never' to $5=$ 'very often' to measure the reading ability of pre-primary 2 pupils. The respondents to appendix III were pre-primary 2 teachers. The researcher conducted pilot study before the final administration of instruments. Four schools which did not participate in the actual study were used for the pilot study. One school from each of the four zones was randomly selected from the list of schools to participate in the pilot study were asked to make comments and suggestions regarding the instructions and clarity of questions asked. The pre-tests raised no concerns as respondents had no problem understanding and answering questions.

This study examined commonly used form of validity test; Face or content validity. To establish face validity of the research instrument, this study used existing scales that had already been validated by other researchers. Further, the research instrument was subjected to critique by experts in the Department of Early Childhood Kenyatta University, school of Education, who assessed the instrument items and terminology to ensure it was clear and logical. The comments on the critique were used to revise the instrument to enhance face validity. Further wording and format modifications were made to improve clarity of the questions and general appearance of the questionnaire. To assess the internal consistency reliability of the measurement scale, Cronbach alpha coefficient was used.

\section{Results}

\subsection{Teacher Working Conditions}

This study sought to describe the working conditions of pre-primary school teachers. Respondents were asked to indicate the frequency to which the statements on the items on teacher working conditions characterised their 
pre-primary schools. Each item had a five point Likert-type scale, ranging from 'never' (1) to 'very often' (5). Data analysis was done using frequencies, means and standard deviations. The results of the analysis are shown in Table 1.

Table 1: Frequencies, Means and Standard Deviations of Teachers' Working Conditions

\begin{tabular}{|c|c|c|c|c|c|c|c|}
\hline & $\begin{array}{l}\text { Never } \\
\text { N } \\
(\%)\end{array}$ & $\begin{array}{l}\text { Rarely } \\
\text { N (\%) }\end{array}$ & $\begin{array}{l}\text { Sometimes } \\
\text { N (\%) }\end{array}$ & $\begin{array}{l}\text { Often } \\
\text { N (\%) }\end{array}$ & $\begin{array}{l}\text { Very } \\
\text { often } \\
\text { N }(\%)\end{array}$ & Mean & $\begin{array}{l}\text { Std } \\
\text { Dev }\end{array}$ \\
\hline Teacher workload & & & & & & 3.62 & \\
\hline $\begin{array}{l}\text { Teachers are expected to mark a } \\
\text { large amount of work }\end{array}$ & $1(1.7)$ & $6(10.2)$ & $13(22.0)$ & $20(33.9)$ & $19(32.2)$ & 3.85 & 1.05 \\
\hline The class has many children & $1(1.7)$ & $13(22.0)$ & $27(45.8)$ & $18(30.5)$ & & 3.03 & .83 \\
\hline $\begin{array}{l}\text { Teachers work for long hours in a } \\
\text { day }\end{array}$ & $1(1.7)$ & $1(1.7)$ & $12(20.3)$ & $30(50.80$ & $15(25.4)$ & 3.97 & .83 \\
\hline School leadership & & & & & & 3.67 & \\
\hline $\begin{array}{l}\text { The school leadership addresses } \\
\text { teachers' concerns } \\
\text { professional development }\end{array}$ & & $6(10.2)$ & $21(35.6)$ & $30(50.8)$ & $2(3.4)$ & 3.47 & .73 \\
\hline $\begin{array}{l}\text { There is effective communication } \\
\text { between teachers and administration }\end{array}$ & & $2(3.4)$ & $23(39.0)$ & $29(49.2)$ & $5(8.5)$ & 3.63 & .69 \\
\hline $\begin{array}{l}\text { There is recognition such as awards } \\
\text { of merit }\end{array}$ & & $1(1.7)$ & $13(22.0)$ & $27(45.8)$ & $18(30.5)$ & 4.05 & .78 \\
\hline $\begin{array}{l}\text { The school administration consults } \\
\text { with teachers before making } \\
\text { decisions that affect them }\end{array}$ & & $8(13.6)$ & $17(28.8)$ & $28(47.5)$ & $6(10.2)$ & 3.54 & .86 \\
\hline
\end{tabular}

As shown in Table 1, the overall mean for teachers' working conditions is 3.58. The overall means for the dimensions of teacher working conditions were: teacher workload is 3.62 and school leadership is 3.67. These results indicate that often the teachers had heavy teacher workload and school leadership often recognized teachers. These results generally agreed with Sergiovanni's (2009) arguments that for teachers to perform well in teaching there should be good administrators who create environments that facilitate teachers to accomplish their tasks.

\subsection{Reading Ability}

This study also examined reading ability of pre-primary school pupils. Respondents were asked to indicate the frequency to which the statements on the items of pupils' reading ability characterized the reading ability of the pupils in their pre-primary schools. Each item had a five point Likert-type scale ranging from 'never' (1) to 'very often' (5). The results of the descriptive statistics are shown in Table 2. 
Table 2: Frequencies, Means and Standard Deviations of Pupils' Reading Ability

\begin{tabular}{|c|c|c|c|c|c|c|c|}
\hline & $\begin{array}{l}\text { Never } \\
\text { N (\%) }\end{array}$ & $\begin{array}{l}\text { Rarely } \\
\text { N (\%) }\end{array}$ & $\begin{array}{l}\text { Sometimes } \\
\text { N (\%) }\end{array}$ & $\begin{array}{l}\text { Often } \\
\text { N (\%) }\end{array}$ & $\begin{array}{l}\text { Very } \\
\text { often } \\
\text { N }(\%) \\
\end{array}$ & Mean & $\begin{array}{l}\text { Std } \\
\text { Dev }\end{array}$ \\
\hline Oral activities & & & & & & 3.17 & \\
\hline Listening actively to stories & $10(16.9)$ & $14(23.7)$ & $9(15.3)$ & $14(23.7)$ & $12(20.3)$ & 1.41 & 1.41 \\
\hline Following simple instructions & $4(6.8)$ & $14(23.7)$ & $20(33.9)$ & $15(25.4)$ & $6(10.2)$ & 3.08 & 1.09 \\
\hline Reciting letters of the alphabet & $6(10.2)$ & $6(10.2)$ & $17(28.8)$ & $14(23.7)$ & $16(27.1)$ & 3.47 & 1.28 \\
\hline News telling of previous events & $9(15.3)$ & $12(20.3)$ & $18(30.5)$ & $12(20.3)$ & $8(13.6)$ & 2.97 & 1.26 \\
\hline $\begin{array}{l}\text { Participating in role playing } \\
\text { activities }\end{array}$ & $5(8.5)$ & $9(15.3)$ & $21(35.6)$ & $15(25.4)$ & $9(15.3)$ & 3.24 & 1.15 \\
\hline Vocabulary & & & & & & 2.78 & \\
\hline Reading hard words clearly & $8(13.6)$ & $26(44.1)$ & $16(27.1)$ & $7(11.9)$ & $2(3.4)$ & 2.47 & 1.34 \\
\hline $\begin{array}{l}\text { Asking for clarification of new } \\
\text { words }\end{array}$ & $10(16.9)$ & $15(25.4)$ & $12(20.3)$ & $13(22.0)$ & $9(15.3)$ & 2.93 & 1.21 \\
\hline Practicing using new vocabulary & $9(15.3)$ & $23(39.0)$ & $10(16.9)$ & $12(20.3)$ & $5(8.5)$ & 2.68 & 1.10 \\
\hline Spelling the words learnt clearly & $6(10.2)$ & $11(18.6)$ & $25(42.4)$ & $11(18.6)$ & $6(10.2)$ & 3.00 & 1.21 \\
\hline $\begin{array}{l}\text { Developing oral vocabulary when } \\
\text { reading alone }\end{array}$ & $9(15.3)$ & $16(27.1)$ & $7(28.8)$ & $11(18.6)$ & $6(10.2)$ & 2.81 & 1.19 \\
\hline Comprehension & & & & & & 2.52 & \\
\hline Constructing meaning in a text & $11(18.6)$ & $29(49.2)$ & $8(13.6)$ & $5(8.5)$ & $6(10.2)$ & 2.42 & 1.19 \\
\hline Understanding what he/she reads & $7(11.9)$ & $24(40.7)$ & $20(33.9)$ & $6(10.2)$ & $2(3.4)$ & 2.53 & .95 \\
\hline $\begin{array}{l}\text { Answering questions } \\
\text { appropriately from a text }\end{array}$ & $9(15.3)$ & $23(39.0)$ & $20(33.9)$ & $5(8.5)$ & $2(3,4)$ & 2.46 & .97 \\
\hline $\begin{array}{l}\text { Making words connection with } \\
\text { pictures }\end{array}$ & $10(16.9)$ & $18(30.5)$ & $16(27.1)$ & 11(18.6) & $4(6.8)$ & 2.68 & 1.17 \\
\hline Overall Mean & & & & & & 2.82 & \\
\hline
\end{tabular}

As shown in Table 2, the mean score for reading ability of pre-primary school pupils was 2.82 . The mean score for oral activities is 3.17 , the mean for vocabulary is 2.78 and the mean for comprehension is 2.52 . All these mean scores indicate that the pupils exhibited ability in oral activities, vocabulary and comprehension occasionally. In general the results reveal that reading ability of pre-primary school pupils was not well developed.

The results are consistent with UNESCO'S (2008) report that showed that a total of 796 million people worldwide were unable to read; 67 million children of school going age were not attending school and 72 million did not get a chance of attending secondary education. The results are also consistent with a study by Davis (2011) which revealed that globally, 20\% of Western Countries like England, Australia and New Zealand children could not read with confidence at the age of 11 years.

The results also support the findings of a study by Anderson and Morgan (2008) which showed that 27\% of children in Maine and $62 \%$ in Louisiana were unable to read and generally $59 \%$ of all the learners were not able to read. The results were also consistent with reports by (NASMLA, 2012) which showed that, slightly less than half $(47.7 \%)$ of the pupils attained the desirable levels of class three and four competency in literacy and about half $(46.1 \%)$ of class three pupils demonstrated emergent reading ability which was congruent with class two levels.

\subsection{Hypotheses Testing}

\subsubsection{Teacher Workload and Pupils' Reading ability}

This study sought to determine the relationship between teacher workload and pupils' reading ability. It was hypothesized $\left(\mathrm{Ho}_{1}\right)$ that there is no relationship between teacher workload and pupils' reading ability. To test the hypothesis, data was analyzed using Pearson's correlation. The results of the analysis are presented in Table 3.

Table 3 Correlation between Teacher Workload and Pupils' Reading Ability

\begin{tabular}{llrr} 
& & Teacher workload & Reading ability \\
Teacher workload & Pearson Correlation & 1 & $-.323^{*}$ \\
& Sig. (2-tailed) & & .013 \\
& $\mathrm{~N}$ & 59 & 59 \\
\hline Reading ability & Pearson Correlation & $-.323^{*}$ & 1 \\
& Sig. (2-tailed) & .013 & 59 \\
\hline
\end{tabular}

* Correlation is significant at the 0.05 level (2-tailed). 
The results in Table 3 indicate $\mathrm{r}=-0.323$ and $p<0.05$. Thus, the hypothesis that there is a relationship between teacher workload and pupils' reading ability is accepted. Thus, it is concluded that there is significant relationship between teacher workload and reading ability. This means that higher workload negatively affect pupils' reading ability.

These findings suggest that teachers are expected to mark large amounts of work, classes have many pupils and teachers work for long hours in a day, this would affect teaching of reading and negatively affect pupils' reading ability.

\subsubsection{School Leadership and pupils' Reading Ability}

The study sought to determine the relationship between school leadership and pupils' reading ability. It was predicted $\left(\mathrm{Ho}_{2}\right)$ that there is no relationship between school leadership and pupils' reading ability. Data was analyzed using Pearson's Product- moment correlation. The results are presented in Table 4.

Table 4 Correlation between School Leadership and Pupils' Reading Ability

\begin{tabular}{llrr}
\hline & & School leadership & Reading ability \\
\hline \multirow{3}{*}{ School leadership } & Pearson Correlation & 1 & .276 \\
& Sig. (2-tailed) & & .038 \\
& $\mathrm{~N}$ & 59 & 59 \\
\hline \multirow{3}{*}{ Reading ability } & Pearson Correlation & .276 & 1 \\
& Sig. (2-tailed) & .038 & 59 \\
\hline
\end{tabular}

The results in Table 4 indicate that there is a positive and significant relationship between school leadership and reading ability $(\mathrm{r}=0.276, p<0.05)$. Thus, the alternative hypothesis is accepted; and this leads to conclusion that there is a significant relationship between school leadership and pupils' reading ability.

These findings suggest that teachers who are given opportunity for professional development seem to promote the academic performance in their respective schools and have skills on how to teach reading well in their schools. School principals who communicate well and give their teachers instructional guidance, resources and also rewarding them for good work done, motivate teachers to do their work well and especially the teaching of reading. The results also suggest that teachers who are provided with opportunities to participate in decision making in matters regarding their class work and more especially in the teaching of reading, seem to be happy and therefore can perform their class work well. Teachers who are free to work and consult other teachers in both classroom work and researching on their pupils' reading abilities, make changes in their teaching methods thereby increase the chances of pupils to learn better.

\section{Discussions}

This study examined the relationship between teacher workload and pupils' reading ability. The results revealed that there is significant relationship between teacher workload and reading ability. These findings suggest that teachers are expected to mark large amounts of work, classes have many children and teachers work for long hours in a day, thus affecting the teaching of reading and therefore negatively affecting pupils' reading ability.

These findings are consistent with findings of a study by Bennett et al. (2002) which revealed that time, inadequate time to prepare, large classroom sizes were some of the factors that affected teachers in teaching of reading. The results also support the findings of a study by Ataphia (2011) which revealed that the degree of concentration of students in overcrowded rooms was low and that class size dictated the teachers' teaching approach. The findings are also consistent with Berry et al.'s (2008) study which revealed that smaller classes such as 25 students per class performed well in reading than classes with large number of pupils, which meant that teacher workload was not heavy, thereby agreeing with the current study that small classes were found to be effective in supporting the reading ability of pupils.

The study also examined the relationship between school leadership and pupils' reading ability. The study demonstrated that there is a significant relationship between school leadership and pupils' reading ability.

The findings of this study is consistent with the findings of a study by Kahenu (2005) which revealed that head teachers' leadership style, promotion policy and physical facilities resulted to high academic performance in schools. Therefore, head teachers who have good leadership styles such as giving teachers chances for professional development and communicating well with them, motivate teachers to teach the pupils well hence, leading to improvement on the pupils' reading ability. Thus the findings of the study empirically confirm the perspective that school leadership determines the reading ability of pupils.

\section{Conclusion}

The study concludes that teacher workload and school leadership affect the reading ability of pre-primary school pupils. Based on the objectives of the study and findings, this study makes the following recommendations for policy and practice as well as further research:

In order to enhance reading ability, the study recommends that pre-primary school classes should have a 
reasonable number of pupils to avoid teacher workload, hence teacher commitment to teach reading. School administrators should practice effective leadership to inspire teachers to be committed to teach reading and improve the reading ability of pupils.

This research could be replicated with private preschools to determine if the findings will be similar or different from those of this study. Secondly, a similar study could be conducted in other Sub-Counties in Kenya to determine if regional differences may influence the relationship between teacher working conditions and pupils' reading ability. Thirdly, this study relied on the teachers' perceptions to determine the reading ability of pre-primary school pupils. A similar study can be conducted using an observation guide or a reading test administered to the pupils. Lastly, there is need for further studies to determine the influence of other factors such as teacher and student characteristics on reading ability. This would help in providing a more comprehensive understanding of the influences of reading ability in pre-primary schools.

\section{References}

Adedeji, S. O. \& Olaniyan, O. (2011). Improving the conditions for teachers and teaching in rural schools across African Countries. UNESCO: International Institute for Capacity Building in Africa.

Adeyinka, A., Asabi, O., \& Adedotum, O. (2013). Role of teacher motivation on students' performance. International Journal of Humanities and Social Science Invention, 2(51), 35 - 41.

Aina, A. J., Okusaga, T. O., Taiwo, A. \& Ogundipe, T. C. (2011). The role of library in promoting reading habits among Nigerians. Journal of research in Education and Society, 2(1), 168-179.

Ataphia, A. D. (2011). Impact of environment on productivity in secondary schools in Nigeria. African Journal of education Technology, 1(1), $116-122$.

Bennett, K. K., Weigel, D. J., \& Martin, S. S. (2002). Children's acquisition of early literacy skills: Examining family contributions. Early Childhood Research Quarterly (17), 295 - 317.

Crouch, L., Korda, M, \& Mumo, D. (2009). Improvements in Reading Skills in Kenya: An experiment in Malindi Distrct. USAID

Danielson, C. (2010). Evaluations that help teachers learn. Educational Leadership 68(4), 35-39. Retrieved from www.ascd.org

Dehaloo, G. (2011). The motivation and job satisfaction of secondary school teachers in Kwazulu-Natal; An education management perspective. Unpublished Doctoral Thesis, University of South Africa.

Elley, W. B. (1991). Acquiring literacy is a second language. The effects of book-based programs. Language Learning, 41(3), 378-411.

Grabe, W. (1991). Current development in second language reading research. TESOL Quarterly. 25(3), 375-406.

Gwambombo, I. (2013). The effect of Teachers' worklord on Studens' Academic Performance in Community Secondary Schools. Unpublished Masters Thesis, Open University of Tanzania.

Ingersoll, R. (2001). Teacher Turnover and Teacher Shortages: An Organizational Analysis. American Educational Research Journal 38(3), 499-534.

Janssen, P. P. M., Schaufeli, W. B. B., \& Houkes, I. (1999). Work-related and Individual determinants of the three burnout dimensions. Work and stress, 13(1), 74-86.

Kahenu, S. M. (2005). Factors influencing motivation and productivity of secondary school teachers. Unpublished Masters Project, Kenyatta University.

Karugu, G. (1980). An investigation of job satisfaction and dissatisfaction among elementary secondary school teachers and education officers in Kenya. Unpublished Doctoral Dissertation, North Illinois University.

Karuoya, F. W. (2015). School related factors influencing standard three pupils' reading ability in Ongata Rongai, Kajiado, Kenya. Unpublished Masters project, Kenyatta University.

King'oo, N. M. (2016). School factors influencing job satisfaction among teachers in public secondary schools in Machakos Town sub-County, Kenya. Unpublished Masters Project, University of Nairobi.

Kirimi, F. K., Gikunda, R. M., Obara, J., \& Kibet, J. (2013). Influence of selected motivational factors on the performance of secondary school agriculture teachers in Imenti South District, Kenya. International Journal of Education and Research 1(6), 1-16.

Leithwood, K. (2006) Teacher working conditions that matter: Evidence for change. Toronto: Elementary Teachers Federation of Ontario.

Lemerle, K. A. (2005). Evaluating the impact of the school environment on teachers' health and job commitment: Is the health promoting school a healthier workplace? Unpublished PhD Thesis, Queensland University of Technology.

Lipson, M. Y. \& Wixson, K. K. (1997). Assessment and Instruction of reading disability. New York: Longman.

Lukhele, B. S. B. (2007). Exploring relationships between reading ability and academic performance. Unpublished Masters Thesis, University of South Africa.

Lusiola, U. A. (2011). Working conditions and their relationship to the level of motivation of preschool teachers in Kegonga Division, Kuria East District. Unpublished Masters Project, Kenyatta University. 
Markel S. (2004). The condition of Teacher quality in Arizona. http://www.Asu.edu.esp/AERI/AEPI annual reports. htm.Retrieved April 2, 2017

Mayeku, B. (2009). Policy guidelines and challenges in quality assurance in distance learning programmes in Kenyan public universities. Unpublished Masters Thesis, Maseno University.

Mwai, W. 2003). Quality of Learning Environment at Early Childhood Education level: Is Kenya on track? Critical perspective on education and post-basic levels. Maseno University.

Mwoma, T. (2017). Children's reading ability in early primary schooling: Challenges for Kenyan Rural Community. Issues in Educational Research, 27(2), 347-364.

Nadeem, M., Rana, S. M., Lone, H. A., Maqbaool, S., Naz, K. \& Ali, A. (2011). Teachers' competencies and factors affecting the performance of female teachers in Bahawalpaur, Pakistan. International Journal of Business and Social Science, 2(19), 486-497).

NASMLA (2012). The national assessment centre monitoring of learner achievement for class 3 in literacy and numeracy in Kenya. Nairobi: Kenya National Examination Council.

Ng'asike, J. T. (2011). Turkana Children's rights to education and indigeneous knowledge in science teaching in Kenya. New Zealand Journal of Teachers' Work, 8(1), 55-67.

Republic of Kenya (2015). Economic survey 2015. Nairobi: Government Printer.

Republic of Kenya (2008). Handbook for early childhood development education syllabus: Nairobi: Government Printer.

Republic of Kenya (2006). Early Childhood Development Service Standard Guidelines for Kenya. Nairobi: Government Printer. 219-234.

Sergiovanni, T. J. (2008). The principalship: A reflective practice perspective $\left(6^{\text {th }}\right.$ Ed.) Texas: Pearson education, Inc. Australia.

UNESCO (2008). Teacher motivation, compensation and working conditions. http://unesdoc.unesco.org/sites/default/files/Guidebook. Retrieved 24/5/2017.

UNESCO (2005). Policy review report: Early childhood care and education in Kenya. http://unesdoc. Org/images/0013/001390/139026e.pdf. Retrieved 24/5/2017.

UWEZO (2015). Are our children learning? The state of education in Kenya in 2015 and beyond. Nairobi: Uwezo Kenya. http://www.uwezo.net/wp-content/uploads/2016/05/05-16-Kenya-small-size.pdf.

Wambiri, G. (2014). Caregiver's role definition and practices in the simulation of children's emergent reading development in Ruiru, Kenya. Journal of Education and Practice, 5(2), 123-31.

Waseka, E. L., Simatwa, E. M. W. \& Okwach, T. O. (2016). Influence of Teacher Factors on Stydents' academic Performance in Secondary School Education. A case study of Kakamega County, Kenya. Greener Journal of Education Research, 6(4), 151-169.

Van, W. A. (2002). Access to higher education in South Africa: Bridging the divide through academic literacy. TESOL Journal, 12(3), 29-34.

Ye, C. (2016). The effect of working conditions on teacher effectiveness: Value added scores and student perception of teaching. PhD Dissertation, Virginia Polytechnic University Institute and State University. 